\title{
Factors Influencing University Students' Academic Achievement and Strategies Taken to Improve Their Achievement: Ethiopia as a Sample
}

\author{
Kelemu Zelalem Berhanu, Akdeniz University, ORCID ID: 0000-0001-5397-8780 \\ Prof.Dr. Ali Sabancl, Akdeniz University, ORCID ID: 0000-0002-2508-7339
}

\begin{abstract}
The overall purpose of this study was to assess heads, teachers, student-affairs officers and students' views about factors influencing university students' academic achievement and strategies taken to improve their achievement at Debre Markos University where found in Debre Markos city of East Gojjam province, Ethiopia. Convenience sampling was used and as a result the working group contained 1head, 1-teacher, 1-students' affair official and 3-students. Interview was used as a data collection method. For this purpose, a semi-structured interview form was developed. The interview form was developed by using theoretical foundations, practices and experiences. The validity of the interview form has been made. The draft form obtained for this purpose was given to two academics, who were experts, for their review, and it was revised in line with their opinions and finalized. As a result, firstly, participants reported university, teachers, language, families and student-related factors as the major factors influencing university students' academic achievement. Secondly, students reported that they were revising past sheet papers and drawing up plans and so on to improve their academic achievement. The head, teacher and students' affair official, however, reported they were giving counseling, training services, complex tasks to improve students' academic achievement
\end{abstract}

Keywords: Academic achievement, Success strategies, Higher Education

\section{Inönü University}

Journal of the Faculty of Education

Vol 21, No 3, 2020

pp. $1165-1180$

DOI: 10.17679/inuefd.559972

Article type:

Research article

\section{Suggested Citation}

Berhanu.K.Z. \& Sabanci, A. (2020). Factors influencing university students' academic achievement and strategies taken to improve their achievement: Ethiopia as a sample. Inonu University Journal of the Faculty of Education, 21(3), 11651180. doi: 10.17679/inuefd.559972

This paper was presented at 9th International Congress on New Trends in Education (ICONTE), 10-12 May, 2018 


\section{Üniversite Öğrencilerinin Akademik Başarılarını Etkileyen Faktörler ve Başarılarını Artırmak için Kullanılan Stratejiler: Etiyopya Örneği}

Kelemu Zelalem Berhanu,Akdeniz Üniversitesi ,ORCID ID: 0000-0001-5397-8780

Prof.Dr. Ali Sabancl,Akdeniz Üniversitesi, ORCID ID: 0000-0002-2508-7339

\begin{abstract}
Öz
Bu çalışmanın amacı Etiyopya'daki üniversite öğrencilerinin akademik başarılarını etkileyen faktörler ve öğrencilerin başarıların artırmak için kullanılan stratejileri incelemektir. Çalışma, nitel araştırma yönteminde ve durum çalışması olarak desenlenmiştir. Bu çalışmanın çalışma grubunun belirlenmesinde uygunluk örneklemesi kullanılmış ve sonuç olarak çalışma gurubu Debre Markos Üniversitesinde görev yapan 1 bölüm başkanı, 1 öğretmen, 1 ögrenci işleri görevlisi ve 3 öğrenciden oluşturulmuştur. Veri elde etme yöntemi olarak görüşme yöntemi kullanılmıştır. Bu amaçla yarı yapılandırımış görüşme formu gelişstirmiştir. Görüşme formu kuramsal dayanaklar, uygulamalar ve tecrübeler kullanilarak geliştirilmiştir. Görüşme formunun geçerli çalışmaları yapılmıştır. Bu amaçla elde edilen taslak form uzman olan iki akademisyene verilerek incelemeleri sağlanmış ve görüşleri doğrultusunda gözden geçirilerek son şekli verilmiştir. Sonuç olarak, katılımcılar üniversite, öğretmenler, dil, aileler ve ögrenci ile ilgili faktörleri üniversite ögrencilerinin akademik başarılarını etkileyen ana faktörler olarak bildirmişlerdir. Akademik başarılarını artırmak için öğrenciler geçmişteki sınavlarda sorulan soruları gözden geçirdiklerini ve bu sorulara dayalı planlar hazırladıklarını belirtmişlerdir. Bölüm başkanı, öğretmen ve öğrenci işleri görevlisi ise öğrencilerin akademik başarıların geliştirmek için danışmanlık, kişisel gelişim kursları, karmaşık görevler içeren ödevler ve projeler verdiklerini belirtmişlerdir.
\end{abstract}

Anahtar Kelimeler: Akademik başarı, Başarı stratejileri,Yüksek Öğrenim.
İnönü Üniversitesi

Eğitim Fakültesi Dergisi

Cilt 21, Sayı 3, 2020

ss. $1165-1180$

DOI: 10.17679/inuefd.559972

Makale türü:

Araştırma makalesi
Gönderim Tarihi : 02.05.2019

Kabul Tarihi : 08.09.2020

\section{Önerilen Atıf}

Berhanu.K.Z. \& Sabanci, A. (2020). Üniversite öğrencilerinin akademik başarılarını etkileyen faktörler ve başarılarını artırmak için kullanilan stratejiler: Etiyopya örneği. Inönü Üniversitesi Eğitim Fakültesi Dergisi, 21(3), 1165-1180. DOI: $10.17679 /$ inuefd. 559972 


\section{INTRODUCATION}

It is clear that education is an important tool that enables citizens to make all rounded participation in the social, political, economic and cultural development process of countries. Education is a fundamental human right enshrined in all major United Nations and International Charters (Igwe, didiamaka \& Chidi, 2017). Education is an avenue of training and learning, especially in schools or university, to improve knowledge and develop skills (Mekonnen, 2014). One of the most important organizations the education takes place is higher institutions that empower students to excel in their academic achievement in a chosen field of endeavor or career, and to be able to positively affect his/her environment. Different scholars define academic achievement of students in different ways. For example, Mekonnen (2014) stated that student's success of students is judged by examination performance while the best criterion of performance is the sum of the student's academic performance in all the subjects taken. When students are getting below the expected stand, according to Armu (2000), called they have poor academic achievement.

Higher institution is place where student possess and discover emotions, feeling, independence and achievement. To order to explain university student's transition and exploration in establishing identity, developing characteristics and growing up in academic performance, Evans and her colleagues (2009), presented the two types of student developmental theories: psychosocial and cognitive. Psychosocial theories involve development as a succession of stages, such as thinking, feeling, behaving, valuing, and relations with other and to oneself. Cognitive theories involve the reconstruction in feelings and thought that form beliefs, values, and assumptions. The cognitive aspects of students' development is the general focus of this study.

When the researchers look at the various studies in related to this study across the globe, the following studies have been conducted. Many empirical studies are carried out to explore factors influencing academic achievement of students (Hijazi \& Naqvi, 2006; Mekonnen, 2014; Mersha et al., 2009; Tiruneh \& Petros, 2014). In order to apply the seven vectors of Chickering's student development theory that contains developing competence, managing emotions, moving through autonomy toward interdependence, developing mature interpersonal relationships, establishing identity, developing purpose and developing integrity on university students, Ortiz (1999), for example, found that living away from home increases leadership and interpersonal skills and cultural awareness of students. This affects students' academic achievement indirectly. Another research finding states that students living at home are "less fully involved" in social, academic, or extracurricular activities in school with others as compared to those students who live in the dorms (Chickering \& Kytle, 1999).

A study conducted by Hijazi and Naqvi (2006) also showed that student performance is associated with students' profile consisted of his attitude towards attendance in classes, time allocation for studies, parents' level of income and mother's age. According to American Psychological Association (APA, 2012), the predictors of dropout are delayed reading skills, grade retention, absenteeism, and school disengagement. With these factors and others as predictors, an Alliance for Excellent Education (2011) estimated 1.3 million American high school students drop-out every year. Peer relationships can create a set of norms and values that either promote or undermine academic achievement. For Latino youth in particular, a significant number are recent immigrants who are English-language learners, i.e., not fully fluent in English and speak another language at home, which exacerbates their risk of dropping out or not completing high school on time (APA, 2012; Fry, 2003). Several risk factors affect children born at the intersection of race and poverty throughout their development predicting school failure or dropout and entry into the juvenile justice system (Children's Defense Fund, 2007).

When the researchers come to the case of Ethiopian higher institutions, Mekonnen (2014); Melese \& Fenta (2009); Mersha et al. (2009);i; Tiruneh \& Petros (2014) just to name few studies about students' academic achievement. Academic dismissal is higher at first year level in Ethiopian's higher institutions. Even the majority of female students with higher aptitude results were dismissed at freshman level. However, the rate of attrition for these groups decreases as the year of the study increases (Mersha et al.,2009). According to the study conducted at Bahir Dar University in Ethiopia, personal-related, university-related, academic-related and economic-related factors were responsible for students' low academic performance and finally caused to dismissal (Mersha et al., 2013). In addition to this, background of students, institutional facilities, and teachers (instructors), method of teaching and evaluation system, interest to subject matter, study style of learners were also affecting students' academic achivemen (Mekonen, 2014). The study conducted by Mersha and his colleagues (2009) also mentioned fear of failure, economic factors and being placed in the departments they are not interested, lack of support from teachers, their entrance exam as factors. 
Other study at Bahir Dar University in Ethiopia University related factors such as university academic and administrative rules and regulations, peer pressure, lack of female role model teachers, department choice of students and providing different supportive trainings and tutorial classes by the university impacts female students' academic performance (Tiruneh, \& Petros, 2014, p.16). Lack of proper guidance, and counselling service, lack of assertiveness training, teachers' gender insensitivity, absence of special support program, and department placement without interest are also main factors students to dropout from the higher learning institutions (Melese, \& Fenta, 2009). Other university-related factors include institutional facilities (lack of resources) like: reference materials, well-organized laboratory equipment's and computer laboratory, and lack of interest to subject matter, were the prior problem that has been seen at RVU Jimma campus. Therefore, the institution should give attention on the infrastructures (Akessa \& Dhufera, 2015).

Regarding on family's background, the studies showed that there is a relationship between mothers' occupation and female students' academic performance (Mersha et al.,2009, Melese \& Fenta,2009), there is strong association between the academic performance of students' GPA and fathers and mothers education level, between the academic achievement (GPA) of students' students and Economic status of families (Akessa \& Dhufera, 2015). Regarding on the off-campus climate, the expansion of khat (Catha edulis, a green stimulant plant leaf) shops, tourist centers and night clubs around the university affect students' academic performance (Tiruneh \& Petros,2014, p.16). Disco houses and traditional Music Houses have detracted females from their persistence on academic work (Mersha et al., 2009).

This is universally acknowledging the fact that good leadership styles important for improving the academic achievement of students. Meta-analysis over 70 studies by Waters et al (2003) demonstrated that there is, in fact, a substantial relationship between leadership and student achievement. That is, just as leaders can have a positive impact on achievement, they also can have a marginal, or worse, a negative impact on achievement. In some studies, they found an effect size for leadership and achievement of .50. Other metaanalysis of 27 studies indicated that the average effect of instructional leadership on student outcomes was three to four times that of transformational leadership (Robinson et al., 2008).

As the summary of many studies under Education Review Office of New Zealand (2015), regarding on the strategies to improve students' academic achievement, firstly, the main task of the schools is to identify the specific needs of students and to build a plan around those needs to raise student achievement for all. In addition to this, in case of the persistent disparities that exist among academic achievement of students, educational administrators set effective targets and create the conditions in which all students can excel will reduce these disparities. Setting the target and then taking effective action requires good information, scrutiny, perseverance and an approach in which all university or school stakeholders are active and committed. Furthermore, leaders may have a positive impact by improving teaching and raising student achievement (Education Review Office, 2015). Many of educational administrators have failed in school leadership because of many management problems relating to institutional planning, human relations, discipline, instructional supervision and community relations experienced which ultimately impact on students' academic performance (Budohi, 2014; Igwe, didiamaka \& Chidi, 2017).

Even if the numerous students are dismissed each year from Debre Markos University, there is no any study that focuses both on factors influencing university students' academic achievement and strategies taken to improve achievement. For filling this gap, the researchers assessed heads, teachers, students' affairs officials, and students' views about factors influencing university students' academic achievement and strategies taken to improve achievement at Debre Markos University, Ethiopia.

The overall purpose of this study was to identify the factors influencing university students' academic achievement and strategies taken to improve achievement. As a whole, this research is believed to have much significance for students, ministry of education, teachers, universities, researchers and concerned citizens by increasing knowledge and information on factors influencing university students' academic achievement and strategies taken to improve achievement. This study examined a number of circumstances and causes that contributes to poor academic achievement of the students. When the problem identified, it is easy to come up with the solution. Thus, this study will show the solution. It also examined some more basic issues, such as the techniques for improving students' academic achievement used by concerned administrators, teacher and students within the university. Therefore, these techniques may be experience for other university's stakeholders. It is also anticipated that based on the findings, those university administrators who are interested in increasing academic achievement of students will explore different approaches to strength students' performance. Finally, the study recommended possible solutions, for the betterment of future of students' academic achievement regarding ways of coping factors affecting their academic achievement. It may also serve as a springboard for other researchers to take in-depth study for further investigation in the field and issue. 
The overall problem statement of this study was - What are heads, teachers, student-affairs officers and students' views about factors influencing university students' academic achievement and strategies taken to improve achievement at Debre Markos University, College of natural and computational science in focus. To answer this major question, the researchers raised the following sub-questions.

What are the factors influencing university students' academic achievement as perceived by the students, teachers, heads, and student-affairs officers?

What are strategies taken to improve academic achievement by the students, teachers, heads, and studentaffairs officers?

What are students, teachers, heads and student-affairs officers' suggestions to improve academic achievement?

\section{Method}

\section{Research Design}

This study was qualitative in nature and employed a holistic single case study since the researchers collected the data from only one university. Because qualitative research is more concern with understanding individuals' perceptions of the world and seeking insights rather than statistical analysis (Silverman, 2005). In qualitative research design, the case study method allows investigators to retain the holistic and meaningful characteristics of real-life events (Yin, 2012). Case studies can establish cause and effect, indeed one of their strengths is that they observe effects in real contexts, recognizing that context is a powerful determinant of both causes and effects. Further, contexts are unique and dynamic; therefore, case studies investigate and report the complex dynamic and unfolding interactions of events, human relations and other factors in a unique instance (Cohen, Manion \& Morrison, 2007).

\section{Working Group}

All regular students, heads, student-affairs officers and teachers at Debre Markos University in Debre Markos in Ethiopia are the target population of this study. For identify this university, the researchers used convenience sampling technique. Debre Markos University has 10,096 regular students and four colleges or faculties. From Debre Markos University's colleges, only College of Natural and Computational has been selected as target of the study since the number of drop out students is high as compared with other colleges (Debre Markos University Registrar office 2016/17 academic year report). Data was collected through interview with maximum variation sampling from a total six, 1-1-1-1-1-1 (teacher, head, students' affairs professional; and first, second and graduate students respectively). This allowed the researchers for the differing and somewhat similar perspectives of each group to emerge and for comparison and at the same time commonality in analysis to occur. Therefore, gathering data from a variety of interviewees depending on the role they play in their university could provide a relatively balanced set of viewpoints and variety of perceptions to analyse.

\section{Data collecting instruments}

In this study, the higher institution viewed as an instrumental case study, because the investigation is on factors affecting the academic achievement of students. In order to investigate heads, teachers, student-affairs officials and students' views about factors influencing students' academic achievement and the strategies taken by them to cope with the problems or factors, a semi-structured interview was employed. Because semi-structured interviews would provide an in-depth exploration of the topic, allowed the researchers to change the order of questions, simplify the questions and to probe the interviews (Cohen et al., 2007). Thus, the mapping of semi-interview questions was carried out in three major levels. Firstly, interviewers were asked an initial question as what are factors affecting the academic achievement of students. What are the strategies that they used to improve students' academic achievement? In the end, participants were asked to suggest for other stakeholders regarding ways of improving the academic achievement of students.

\section{Data analysis techniques}

There is no one way to analyze and present qualitative interview data. The literature does suggest using three steps, which are labelled as organizing, summarising and interpreting as a guide to data analysis (Ary et al., 2002). For organizing data, the researchers looked the notes that they have taken on the sheets of paper at the time of each interview and noting down the similarities, themes, and interesting responses. If there is missing information, the researchers were listening to the digital recording of the complete interviews repeatedly as necessary. After that, the researchers were made the interview data fully transcribed. The researchers sent a transcription of the interviews to each participant for checking and they invited to make any corrections. The step of summarising by finding common themes involved 
looking for repeating words and phrases and categorizing these into similar groups. The last stage is interpretation where the data were examined, analyzed, contrasted and compared. In addition, data analysis process was aided by the use of a qualitative data analysis computer program called NVIVO, which used to facilitate and assist to analyze the data that have qualitative in nature. That is NVIVO does not perform the analysis but only supports the researcher doing the analysis by organizing data (Cohen et al., 2007).

\section{Validity, Reliability and Ethical consideration}

Prior to data collection, the researchers sought approval to conduct research in the specified area and to explicitly seek the consent of participants who were involved in this research and to ensure as their response will be kept confidential, the purpose of the study was explained. The participants were also informed that they could discontinue their participation at any time. Each participant was contacted and a convenient location and time were determined for the interview. Prior to the interview, the researchers were asked the participants to sign a consent form.

Reliability relates to being consistent over time with methods and treating all groups the same when gathering data. Validity is achieved when the researcher's data gathering relates to the concept being studied so it is in line with the actual research aim (Cohen et al., 2007). In order to establish reliability and validity within this study, the following steps were implemented. Prior to interviewing, the researchers checked both sets of interview questions against the aim and key questions. After that, the researchers gave interview questions to two academics who were experts on the topic to ensure its content validity. In order to ensure whether the participants can understand the question or not, field-test with two teachers and one student was carried out.

\section{Findings}

This chapter presented analysis of the data collected through interview from Debre Markos University's students, teacher, head, and students' affairs professional. All the six participants were from Debre Markos University in Ethiopia. There were three from each group (teacher, head, and student-affairs officer on one side and students on other side). This chapter organized their responses based on research questions-first, the factors influencing the academic achievement of university students as perceived by the students, teacher, head, and students' affairs professional; second, the strategies taken by students, teachers and other concerned administrators to tackle students' academic achievement-related problems. Finally, students, teachers, heads and students' affairs professionals' suggestions to improve students' academic achievement were presented. In addition, the head, students' affair official and teacher responses were analyzed independently from students starting from first year to third year.

To do these, NVIVO was employed in the analyses of the variables under consideration. It was organized into three parts. These are:

\section{The factors influencing university students' academic achievement}

This part has two sub-parts- first students' views and second head, students' affair official and teacher's views about the factors influencing the academic achievement of university students in table 1 and 2 were presented.

\section{A. Students' views about the factors influencing university students' academic achievement}

At the beginning of the interview, students were asked about the factors influencing university students' academic achievement and follow up questions related to this. And, the views of students' perceptions about the factors influencing the academic achievement of students were given in table 1 
Table 1.

Students' Views About the Factors Influencing University Students' Academic Achievement

\begin{tabular}{|c|c|c|c|c|}
\hline \multirow{2}{*}{$\begin{array}{l}\text { Interview } \\
\text { Guidelines }\end{array}$} & \multirow[t]{2}{*}{ Themes } & \multicolumn{3}{|c|}{ Participants' response } \\
\hline & & 1-year & 2-year & 3-year \\
\hline \multirow{10}{*}{$\begin{array}{l}\text { The factors } \\
\text { influencing } \\
\text { university students' } \\
\text { academic } \\
\text { achievement }\end{array}$} & Student-related factors & $\checkmark$ & $\checkmark$ & $\checkmark$ \\
\hline & Teacher- related factors & $\checkmark$ & $\checkmark$ & $\checkmark$ \\
\hline & University-related factors & $\checkmark$ & $\checkmark$ & $\checkmark$ \\
\hline & Language- related factors & $\checkmark$ & $\checkmark$ & \\
\hline & Off campus climate- related factors & & & $\checkmark$ \\
\hline & Peer- related factors & $\checkmark$ & & \\
\hline & $\begin{array}{l}\text { Administrative leadership styles and } \\
\text { behaviours related factors }\end{array}$ & $\checkmark$ & & \\
\hline & $\begin{array}{l}\text { Distance between home and university- } \\
\text { related factors }\end{array}$ & & $\checkmark$ & \\
\hline & $\begin{array}{l}\text { Low status perception for teaching } \\
\text { profession- related factors }\end{array}$ & & $\checkmark$ & \\
\hline & Voilence-related factors & & & $\checkmark$ \\
\hline
\end{tabular}

Table 1 summarized categorization of responses based on Debre Markos University's students' views on the factors influencing their academic achievement. As showed, the responses were classified into ten main themes. All of them reported university, teachers, and students- related factors are the major factors influencing students' academic achievement at Debre Markos University. Then two of three also attributed the factors to language. Students' views in-depth showed below:

Student-related factors-include students' personal matters such as lack of adequate effort, lack of selfconfidence, carelessness, lack of ability to be competent, afraid of exam, psychological stress, unable to study, previous academic background (high school and preparatory school),studying during only a quiz or test, irregular class attendance, lack of class attention, lack of revision after class, lack of class participation, students' perceptions of their current learning environment, poor study skills, poor time management, health related factors, wasting their time with unnecessarily place are the major factors influencing students' academic achievement. Students' opinions on the subject were directly cited below.

For example, the student gets lazy and when students study only when there is a quiz or test, they do not well master the courses and get poor performance (2-year student), some female students have contacts in the towns with brokers to work as sex workers for money. That is, the brokers call them in the night whenever they are wanted. I think they did it to satisfy their financial requirements and some females for leisure and wasting their time with such unnecessarily place attributed their low academic performance (3-year student).

Teacher-related factors-Teachers' motivation, teaching load, teachers' punctuality to cover their syllabuses on time, salary, working conditions, knowledge on how to catch the attention of a student and the subject matter, communication ability, emotional stability, good human relationship and interest in the job are teachers-related factors influencing students' academic achievement.

A second-year student reported directly as -"Teacher motivation plays a key role in the success of students. Teaching profession does generally not have a very good reputation due to the low social status of teachers in society, a relatively low salary, and poor working conditions. These problems lead to a strong dissatisfaction among the teachers and to a fluctuation process and directly affect students' academic achievement".

University-related factors-Lack of accessible resources such as the computer, internet access, adequate toilet houses, comfortable classrooms; lack of adequate social and academic orientation for first years students, lack of proper use resources, lack of availability of university 's programs based on students' interest.

For example, a 3-year student reported the University-related factors as -"For me; there are enough resources but the university does not use properly. For example, there are enough toilet rooms but they are too dirty and not remove properly on time. They are full and not under usage, which indirectly affects academic achievement. Adjustment problems can also affect students since the university is new for firstyear students.

Language-related factors- the change of instructional language from the native language to English. Change of instructional language from the native language to English even if it starts from secondary 
school also affects students' academic achievement.

Off-campus climate-related factors-off campus communities and Disco houses as factors influencing students' academic achievement.

As a third-year student reported, "A very few girls are mostly victims of sexual harassments by community people in the city. Because of these harassments, female students have indicated that they have stopped to go to the city especially at evening for recreation". In addition, she added her observation about offcampus factor as follows:

There are 5 male students have rented their own house outside of the university so as to pass the nights after enjoying in Disco houses. Most of them are coming from big cities such as Addis Ababa, Hawasa, Dire Dawa and Bahirdar. They were wasting their time with the unnecessary place and have a poor academic performance.

Peer-related factors- peer are also affecting students' academic achievement both in negative and in positive ways.

Administrative leadership styles and behaviors related factors- as the first-year student told,

Leadership styles and behaviors have an impact on students' academic achievement. For me, it has an effect both positive and negative but our head, college dean have a positive impact since they are experiencing the democratic type of leadership.

The distance between home and university-related factors-When students live far from home, they feel depressed and, which, in turn, affect students' academic achievement (2-year student).

Low-status perception for teaching profession- related factors- includes dignity students and society attached to teaching a profession can affect students' academic achievement indirectly. This has been more explained to a participant as follows:

Teaching profession does generally not have a very good reputation due to the low social status of teachers in society, a relatively low salary, working conditions. These problems lead to a strong dissatisfaction among the teachers and directly affect students' academic achievement (2- year student).

Violence-related factors- as participants reported, some female students were encountered verbal and physical harassment by male students, teachers, other university communities and off-campus communities.

A very few girls are victims of sexual harassments by senior community people in the city and some instructors who mostly target to use their grades as a means. When they apply for university administration, they request them to give witness. However, most of the female students did not take courage to expose themselves in front of some people and as a result, refuse to give their witnesses about what the instructors had committed on them. However, some teachers have punishment for involving in such ugly activities (3year student).

B. Head, student-affairs officer and teacher's views about the factors influencing university students' academic achievement

At the beginning of the interview the head, student-affairs officer and teacher were also asked about the factors influencing university students' academic achievement and follow up questions related to this. Their responses were given in table 2 .

Table 2.

Head, Student-Affairs Officer and Teacher's Views About the Factors Influencing University Students' Academic Achievement

\begin{tabular}{|c|c|c|c|c|}
\hline \multirow{2}{*}{$\begin{array}{l}\text { Interview } \\
\text { Guidelines }\end{array}$} & \multirow[t]{2}{*}{ Themes } & \multicolumn{2}{|c|}{ Participants' } & response \\
\hline & & Head & $\mathrm{SAO}$ & Teacher \\
\hline \multirow{8}{*}{$\begin{array}{l}\text { The factors influencing } \\
\text { university students' } \\
\text { academic achievement }\end{array}$} & University- related factors & $\checkmark$ & $\checkmark$ & $\checkmark$ \\
\hline & Student- related factors & $\checkmark$ & $\checkmark$ & $\checkmark$ \\
\hline & Family-related factors & $\checkmark$ & $\checkmark$ & $\checkmark$ \\
\hline & Language- related factors & $\checkmark$ & & $\checkmark$ \\
\hline & Teacher- related factors & $\checkmark$ & & $\checkmark$ \\
\hline & Off-campus climate- related factors & & $\checkmark$ & \\
\hline & $\begin{array}{l}\text { Administrative leadership styles and } \\
\text { behaviours }\end{array}$ & & & $\checkmark$ \\
\hline & $\begin{array}{l}\text { The distance between home and } \\
\text { university }\end{array}$ & & $\checkmark$ & \\
\hline
\end{tabular}

Note SAO stands for student-affairs officer

As in table 2 indicated, the responses were classified into eight main themes. 
All of them reported university, families and student-related factors are the major factors influencing students' academic achievement at Debre Markos University. Then two of three (66.6\%) also attributed the factors to Language and teachers.

University-related factors- lack of orientation and proper guidance, lack of resources like reference materials, well-organized laboratory equipment's and computer laboratory, the placement of university near to the city and poor capacity building activities are factors influencing students' academic achievement. Because of limitation of space, some participants' opinions on the subject were cited below.

When students far from their families, they might get difficult to adopt the new environment and way of life. Especially in case of lack of orientation in the university for freshman students, it becomes worse. Moreover, the longer these students stay in the universities, the number of dismissal decreases from year to year. This might be attributed to the problem of adjustment at first-year level and lack of orientation and proper guidance and counseling (head).

Students' affair official also described, "The placement of university near to the city encourages students to involve in unnecessary places and things such as disco, drinking alcohol and instead of focusing on their education".

Student-related factors- students' the prior academic achievement, psychological distress, lack of good background and interest in the department, lack of support and belief in students' abilities, lack of know how to learn, absenteeism and school disengagement are the factors influencing students' academic achievement. For example, as a head described:

The prior academic achievement and psychological distress such as stress, anxiety, and depression especially at first year might account for students' academic achievement. The issue of self-independence also another factor affecting students' academic achievement at a university level.

Moreover, at the last, as a teacher mentioned:

Lack of interest to the department they have been assigned, lack of students' effort to do their best affecting their academic achievement.

Family-related factors-Parenting styles and socio-economic status of families are factors affecting students' academic achievement.

Language-related factors-Students have a serious English language proficiency problem because of a disparity between media used language and medium of instruction, unavailability of opportunities to use English language except in the class, which affect students' academic achievement.

A teacher explained about it as follows:

As I observed, students have a serious English language proficiency problems. Students' language is poor because poor capacity building activities, unavailability of opportunities to use the language except in the class. In Ethiopia, English was still rarely used in the media. Even if the total number of newspapers has increased dramatically, the English-based television programs made by Ethiopian are a few. That means there is a disparity between media used language and medium of instruction, which affects students' academic achievement.

Teacher-related factors- Giving less rigorous assignments to students, teachers' leadership styles and behaviours in the class and assessing methods are factors influencing students' performance (as head and teacher mentioned)

For example, as a teacher' $s$ described "Assessing learning progress of students before or during the learning process itself rather than summative assessing after the teaching is done to make learning process more visible to learners"

Off-campus climate-related factors- Unnecessarily places and things near to university such as disco, drinking alcohol houses made students not to focus on their education. In addition, students' affair official also added that:

The community that is off campus also affects students. Before months ago, bajaj driver harassed a female student and now with collaboration of police, he has appropriate punishment.

Administrative leadership styles and behaviors- As a teacher stated," Administrators such as heads' leadership styles and behaviors are also influencing students' academic achievement. University administrators experienced might affect students' academic success directly or indirectly. When I say indirectly, they affect teachers' performance and motivation, which in turn affect students' performance"

The Distance between home and university- Even if the majority of students' families are near by the university such as Gonder, East Gojjam and West Gojjam, the distance of university from their parents are affecting students' academic achievement since it creates some psychological distress (student-affairs officer).

\section{Strategies taken to improve academic achievement}


This part also has two sub-parts- firstly students' views and secondly head, student- affairs officer and teacher's views about the strategies they taken to improve academic achievement of students in table 3 and 4 were presented.

\section{A. Students' views about the strategies they taken to improve their academic achievement}

Secondly, students were asked about the strategies they taken to improve their academic achievement and follow up questions related to this. In addition, the views of students about the strategies they taken to improve their academic achievement were given in table 3.

Table 3.

Students' Views About the Strategies They Taken to Improve Their Academic Achievement

\begin{tabular}{|c|c|c|c|c|}
\hline \multirow{2}{*}{$\begin{array}{l}\text { Interview } \\
\text { Guidelines }\end{array}$} & \multirow[t]{2}{*}{ Themes } & \multicolumn{3}{|c|}{ Participants' response } \\
\hline & & 1-year & 2-year & 3-year \\
\hline \multirow{9}{*}{$\begin{array}{l}\text { Strategies they } \\
\text { taken to } \\
\text { improve } \\
\text { academic } \\
\text { achievement }\end{array}$} & Revising past sheet papers & $\checkmark$ & $\checkmark$ & \\
\hline & Drawing up plans & & $\checkmark$ & $\checkmark$ \\
\hline & Establishing a good relationship with teachers & & $\checkmark$ & \\
\hline & Increasing ownership & $\checkmark$ & & \\
\hline & Receiving guidance and counselling & & $\checkmark$ & \\
\hline & Consolidation & & & $\checkmark$ \\
\hline & Searching out different materials from Google & & & $\checkmark$ \\
\hline & Studying very hard & $\checkmark$ & & \\
\hline & Teamwork & & $\checkmark$ & \\
\hline
\end{tabular}

As Table 3 showed, the responses were classified into nine main themes. Two of three (66.6\%) students stated that revising past sheet papers and drawing up plans were the strategies they used to improve their academic achievement. They have also taken unique strategies. Here are their strategies:

Revising past sheet papers-top among the most important measure taken by students include getting past project sheet or assignment and try to solve it in order to know their gaps and work on their limitation. For example, as a second-year student described:

If there is an availability of past papers or assignments, I ask my senior students to review past assignments and exams to unearth my most common mistake.

Draw up plans- 3 and 2-year student stated that they draw up the plan to study. They expressed their ideas as follows:

I also start my assignments on the day the teachers are given the topic to work on. If I leave all my assignments or tasks until the very last minute, I might feel overwhelmed and stressed out (3-year student). A 2-year student added on it that" in order to, I feel less overwhelmed nearby the exam, I make a plan of study, which helps me to know where to begin when I start studying.

Establishing a good relationship with teachers- a second-year student expressed the importance of having a good relationship with teachers as -

I establish a good relationship with my teachers, which is important for my academic and social development. Because it is the big way to receive more constructive guidance and praise.

Increasing ownership-a first-year student stated that he tried to increase his ownership for improving his academic achievement by motivating myself to study and by getting a rest, carefully listen to a lesson, participate in the lesson by asking and listening questions, which helped him to adopt the constructivist approach.

Receiving guidance and counseling- A second-year student reported that

I have received more constructive guidance and praise rather than just criticism from my teachers to improve my academic success.

Consolidation-A third-year student announced her way to tackle his academic-related problems as I have a habit of study what I have learned in the classroom within 24 hours. And then I take a rest which in turn gives me energy, enhances productivity and concentration, I do not study much at the time of exam since I have studied it before.

Searching out different materials from Google- is also means used by a third-year student when he has faced a difficulty.

Studying very hard- a first-year student stated about his of tackling academic related problems as follows: Even though there is lack of resources in our university, I am trying my best to become successful in my academic achievement. First, I study very hard and then motivate myself by getting a rest. I carefully listen to a lesson is already taking a big step on the road to my success. 
Teamwork- Finally, a second-year student described the way that his teamwork style seems as follows:

I study with classmates to receive and help from students who may understand certain aspects of the courses better than I do. Sometimes, if it is more than our capacity, we ask senior students to share their knowledge about the material.

B. Head, student-affairs officer and teacher's views about the strategies they taken to improve students' academic achievement

Secondly, head, student-affairs officer and teachers were asked about the strategies they taken to improve students' academic achievement and follow up questions related to this. And, the views of head, studentaffairs officer and teacher's perceptions about the strategies they taken to improve students' academic achievement were given in table 4.

Table 4.

Head, Student-Affairs Officer and Teacher's Views About the Strategies They Taken to Improve Students' Academic Achievement

\begin{tabular}{|c|c|c|c|c|}
\hline \multirow[t]{2}{*}{ Interview Guidelines } & \multirow[t]{2}{*}{ Themes } & \multicolumn{3}{|c|}{ Participants' response } \\
\hline & & Head & SAO & Teacher \\
\hline \multirow{8}{*}{$\begin{array}{l}\text { 2. The strategies } \\
\text { they taken to } \\
\text { improve students' } \\
\text { academic } \\
\text { achievement }\end{array}$} & Giving counseling and training services & & $\checkmark$ & $\checkmark$ \\
\hline & $\begin{array}{l}\text { Giving more and complex } \\
\text { tasks }\end{array}$ & $\checkmark$ & & \\
\hline & Increasing ownership & & & $\checkmark$ \\
\hline & Reinforcement & & & $\checkmark$ \\
\hline & $\begin{array}{l}\text { Solving economic, psychological and } \\
\text { community based problems }\end{array}$ & & $\checkmark$ & \\
\hline & Teamwork & $\checkmark$ & & \\
\hline & Using formative techniques & & & $\checkmark$ \\
\hline & Draw up plans & & & $\checkmark$ \\
\hline
\end{tabular}

As in the table 4 depicted, the responses were classified into eight main themes. Though they experienced one measure in common like giving counseling and training services, they have also taken other unique strategies to cope up with students' academic achievement-related problems.

Let us see in-depth what participants were said:

Giving counseling and training services- student-affairs officer stated that "Fresh students have been given training about how to learn, campus climate, time management, assertiveness skills, give counseling service to students who are in need". The teacher also reported his measure of giving advice and showing the direction to low achievers.

Giving more and complex tasks- A head described giving more and complex task as follows:

To improve students' academic achievement what I did and doing just as a head and teacher is that giving more and complex tasks to students. Many teachers will tell you that they gave rigorous assignments when in reality, it was not. This one thing will make the biggest impact not only on their learning but also on their scores.

Increasing ownership- teacher reported, "I allow students to take ownership of their education by involving students to do their best".

Reinforcement-A teacher stated his action to tackle students' academic-related problems as follows:

To improve students' academic achievement, I celebrate students' strengths by offering rewards i.e, giving positive appreciation to high achievers and giving advice. I used reinforcement just in the classroom by saying, named students, "Good Job!"

Solving economic, psychological and community-based problems- student-affairs official described the ways of solving economic, psychological and community-based problems as:

To solve students who have economic problems, we give a job as waiter and waitress in students' cafeteria and they earn money and psychological problems by counseling. Moreover, we try to solve community-based problems such as sexual harassment with the collaboration of police.

Teamwork- One participant described it as follows:

I encouraged teamwork in every aspect. As a university rule, we create teams, which contain five students, and they have their own head. They help each other. Department' instructors have also regular staff meetings and get together to foster team building in our department and to enhance students' performance (head).

Using formative techniques- A teacher also described his ways assessment to improve students' academic achievement as follows: 
I am assessing learning progress of students before or during the learning process itself rather than summative assessing after the teaching is done to make the learning process more visible to learners.

Draw up plans- teacher noted that" I keep the focus on improvement and draw up plans on how students are going to improve on their weaknesses and implement it".

3. The suggestions to improve academic achievement

Lastly, this finding part has two sub-parts like others- firstly students' suggestions and secondly head, students' affair official and teacher's suggestions to improve students' academic achievement in table 5 and 6 were presented respectively.

\section{A. Students' suggestions to improve academic achievement}

At the end of the interview, students were asked about their suggestions to improve academic achievement. Their responses were given in table 5 .

Table 5.

Students' Suggestions to Improve Students' Academic Achievement

\begin{tabular}{|c|c|c|c|c|}
\hline \multirow{2}{*}{$\begin{array}{l}\text { Interview } \\
\text { Guidelines }\end{array}$} & \multirow[t]{2}{*}{ Themes } & \multicolumn{3}{|c|}{ Participants' response } \\
\hline & & 1-year & 2-year & 3- year \\
\hline \multirow{8}{*}{$\begin{array}{l}\text { The suggestions to } \\
\text { improve academic } \\
\text { achievement }\end{array}$} & University-based suggestions & $\checkmark$ & $\checkmark$ & $\checkmark$ \\
\hline & $\begin{array}{l}\text { Administrators of university-based } \\
\text { suggestions }\end{array}$ & & $\checkmark$ & $\checkmark$ \\
\hline & All stakeholders-based suggestions & $\checkmark$ & $\checkmark$ & \\
\hline & Students-based suggestions & $\checkmark$ & $\checkmark$ & \\
\hline & Teachers-based suggestions & $\checkmark$ & $\checkmark$ & \\
\hline & Students' affair officials-based suggestions & $\checkmark$ & & \\
\hline & $\begin{array}{l}\text { Other Education Bureaus and NGOs-based } \\
\text { suggestions }\end{array}$ & & & $\checkmark$ \\
\hline & Parents-based suggestions & & $\checkmark$ & \\
\hline
\end{tabular}

As in table 5 displayed students' suggestion based on their experiences for other stakeholders regarding ways of improving students' academic achievement were summarized. Here are their responses:

University-based suggestions- all students have given suggestions what a university should do to improve students' academic achievement. Both first and third-year students' suggested that the university should organize recreation site within a university to encourage greater student involvement with could be a highly productive activity on most university campuses; and to keep students from off-campus influences. The first-year student also added the university and students' affair officials should give sound counseling to students, provide staff training, and organize academic symposiums about the students' academic achievement. In addition to these, the second-year student stated that a university should understand the students need for English language and the challenges they face and then establishes the English language center to alleviate the problems. Finally, a third-year student added the university should use resources such as water, library, and other equipment properly and have a discussion with students' representative at least twice a month to tackle the barriers for students' academic achievement.

Administrators of university-based suggestions-a second-year student said, "The administrators of higher education institutions should have also an understanding that they can have strong effects on students' academic self-efficacy and achievement. A third-year student added, "They have to organize workshops, seminars, and conferences about the issues factors affecting students' performance and make a discussion with students' representative".

All stakeholders-based suggestions- Both a first and second-year student recommended:" All stakeholders of the university are responsible and do their best to enhance students' academic achievement".

Students-based suggestions -include "Students should create a free interaction with teachers, participate in honours programs gain substantially in interpersonal self-esteem, intellectual self-esteem, and artistic interests, involve academically and less susceptible to become less susceptible to the peer group influences" (first-year student). A second-year student also added to it by suggesting students to study day and night until achieving our objectives.

Teachers-based suggestions-include" Teachers should be setting and communicating clear learning objectives, providing clearly structured explanations, examples and guided practice to students at the beginning of the class" (first-year student). In addition, a second-year student suggested teachers to understand that they can have strong effects on students' academic self-efficacy and achievement; and establish, and maintain supportive and appealing pedagogical environments. 
Student-affairs officers-based suggestions-a first-year student suggested:" Students' affair officials should give sound counseling".

Other Education Bureaus and NGOs-based suggestions- "Ministry of Education should set workable policy guideline that will be implemented by all higher learning institutions to protect female students from being harassed and organize a scheme to help those female students who face economic problems and keep them from an unnecessary place "(third-year student).

Parents-based suggestions- A second-year student finally recommended to parents of students to help and support their children economically, psychologically.

B. Head, student-affairs officer and teacher's suggestions to improve academic achievement

Lastly, head, student-affairs officer and teacher's suggestions to improve academic achievement were given in table 6.

Table 6.

Head, Student-Affairs Officer and Teacher's Suggestions to Improve Academic Achievement

\begin{tabular}{|c|c|c|c|c|}
\hline \multirow[t]{2}{*}{ Interview Guidelines } & \multirow[t]{2}{*}{ Themes } & \multicolumn{3}{|c|}{ Participants' responses } \\
\hline & & Head & SAO & Teacher \\
\hline \multirow{4}{*}{$\begin{array}{l}\text { The suggestions to } \\
\text { improve academic } \\
\text { achievement }\end{array}$} & University-based suggestions & $\checkmark$ & $\checkmark$ & $\checkmark$ \\
\hline & Teachers-based suggestions & & $\checkmark$ & $\checkmark$ \\
\hline & Students-based suggestions & $\checkmark$ & & \\
\hline & $\begin{array}{l}\text { Other education bureaus-based } \\
\text { suggestions }\end{array}$ & & & $\checkmark$ \\
\hline
\end{tabular}

As shown in table 6, head, student-affairs officer and teacher suggested for a university to improve the academic achievement of students. Furthermore, their responses were shortly presented below:

University-based suggestions- All participants have given suggestions to university to improve students' academic achievement. From these, a few suggestions include: gives attention on the infrastructures and access of laboratory equipment, provides proper learning facilities to the students, devises means of paying special attention to students from low social economic backgrounds, believes in the students' abilities, recruits more counselors to each college and creates a good classroom environments .

For example, a students' affair official stated, "University should recruit more counselors to each college. Just now we are only two counselors for two campus (Burie and Debre Markos), which have more than 15,000 students, which is very insufficient to give counseling services. In addition, the university should be given adequate learning facilities that causes improvement in student performance".

Teachers-based suggestions- teacher suggested for other teachers as "Teachers should be providing formative evaluation techniques before closing up the lesson, and teachers need to give a chance to each student takes a turn at being the "teacher", and often the teacher and students take turns leading a dialogue concerning sections of a text"

A students' affair official also added on it by reported "Teachers and university need to create classroom environments where error is welcomed as a learning opportunity, where discarding incorrect knowledge and understandings is welcomed, and where participants can feel safe to learn, relearn, and explore knowledge and understanding; and believing in the students and offering support throughout the school year can help improve their achievement levels".

Other education bureaus-based suggestions-Teacher also suggested that "the Ministry of education should establish English language center or use national language as a medium of instruction at higher institutions level".

Students-based suggestions- Selected head also suggested, "Students must study very hard by using accessed resources to improve their academic achievement".

\section{DISCUSSION,CONCLUSION AND RECOMMENDATIONS}

The overall aim of this study was to identify factors influencing university students' academic achievement and strategies used to improve as a teacher, head, students' affair official and students' perceived. The researchers found from the study that improving students' academic achievement was a big challenge at Debre Markos University. The overall problem statement of this study is -heads, teachers, students' affair officials and students' views about factors influencing university students' academic achievement and strategies taken to improve their achievement at Debre-Markos University. To answer this major question, the researcher raised the following three sub-questions. Firstly, students, heads, teachers, students' affair 
officials were asked factors influencing students' academic achievement and, all students reported university, teachers and student-related factors are the major factors influencing students' academic achievement at Debre Markos University. Then two of three also attributed the factors to language. In another side of the group, all head, student affair official, and teacher reported university, families and student-related factors are the major factors influencing students' academic achievement at Debre Markos University. Then two of three also attributed the factors to Language and teachers. This finding consistent with a study conducted in the USA (Alliance for Excellent Education, 2011, American Psychological Association, 2012), which found the predictors of students' academic achievement are students' background such as delayed reading skills and peer relationships. Langauge also noticed as a factor for those who speak another language (out of medium of instruction) at home, which exacerbates their risk of dropping out or not completing school on time (Fry, 2003, American Psychological Association, 2012). The study also coherent with the study of Mersha et al.,2009, Mersha et al, 2013,Tiruneh, \& Petros,2014, p.16) at different universities in Ethiopia, that factors generally classified as on-campus and off-campus.

The study also inconsistent with some finding of Tiruneh, \& Petros(2014) such as lack of female role model teachers and the expansion of khat (Catha edulis, a green stimulant plant leaf that affects students' academic performance, which was not mentioned by any participant in this study. In addition, the present study also does not fit with the finding of Mershaet al.,2009, Melese.\& Fenta, 2009, which stated mothers' occupation as a factor. However, this finding is congruent with the study of Melese.\& Fenta(2009)- who they stated lack of proper guidance, and counseling service, lack of assertiveness training, teachers gender insensitivity, the absence of special support program as factors. In addition, this study has also a consistent with the study of Melese, \& Fenta (2009);Mekonnen(2014); Akessa \& Dhufera (2015) on department placement without interest as main factors students to drop out and to have a low academic achievement. The study also consistent with Waters et al. (2003) and Robinson et al. (2008) that found leadership has a positive and negative impact on student academic achievement.

Secondly, the researchers were asked about what were the measures taken by students and administrators to tackle students' academic achievement-related problems. As Table 3 showed, the students' responses were classified into nine main themes. From these, two of three students, which include revising past sheet papers and drawing up plans, they have taken unique measures are measure taken by students. Heads, teachers, students' affair officials responses' were classified into eight main themes, and two of three administrators, which giving counseling and training services. Regarding on all participants' strategies and suggestions, the present study has more or less consistent with the study of Waters (2003) that reported leader should focus on change that is, whether leaders properly identify and focus on improving the school or university and classroom practices that are most likely to have a positive impact on student achievement in their school or university. Participants' suggestions also have a line alignment with the summarized report of Education Review Office(2015).

At the end of the interview, students and administrators were asked to suggest based on their experiences for other stakeholders regarding ways of improving students' academic achievement. All students have given suggestions what a university should do to improve students' academic achievement such as organizes recreation site within a university to encourage greater student involvement and to keep students from offcampus influences. Another group i.e heads, teachers, and students' affair officials have given suggestions to university to improve students' academic achievement such as giving attention on the infrastructures and access of laboratory equipment.

Based on the findings, the researchers have made the following recommendations and implications:

1. The researchers also believed all suggestions recommended by a head; teacher, students' affair official, and students should be considered and have been given value.

2. The teachers and students' affair officials should be realizing self-esteem of the pupils, which are constructive approaches to preventing students from getting low academic performance.

3. To tackle the students-academic achievement-related problems, the administrators should advocate and give their ears to students' views and problems.

4. All University's administrators and teachers should be committed to improving students' academic performance by removing barriers hamper students academic achievement in a professional manner.

5. A study needs to be carried out on both sides of students and administrators by asking more participants to see whether findings from the study will encounter with the ones from this research. In this regards, with 
greater involvement of all stakeholders of the school, there is a need to conduct an action-research for scanning the internal and external environment pertaining to the low academic achievement of students.

6 . Studies that are more comprehensive should be undertaken by including a larger population in order to establish whether the problem transcends other Universities

\section{REFERENCES}

Akessa, G., \& Dhufera, A. (2015). Factors that influences students academic performance: A case of Rift Valley University,Jimma, Ethiopia. Journal of Educationand Practice, 6(22), 55-63.

APA. (2012). Facing the school dropout dilemma. Washington, DC: Author: American Psychological Association. http://www.apa.org/pi/families/resources/school-dropout-prevention.aspx. adresinden alındı

Aremu, A. (2000). Academic Performance 5 Factor Inventory. Ibadan: Stirling-Horden.

Ary, D., Jacobs, L., \& Razavieh, A. (2002). Introduction to research in education(6thed.). Belmont: Wadsworth/Thomson Learning.

Budohi, L. A. (2014). The effect of principals' leadership styles on The academic achievement of student in public secondary schools in Lurambi division, Kakamegacounty Kenya(Unpublished Master's Thesis). Kenyatta University:Kenya.

Chickering, A. W., \& Kytle, J. (1999). The collegiate ideal in the twenty-first century. J. D. Toma, \& A.J.Keza(Eds.) içinde, Reconceptualizing the collegiate ideal (s. 109-120). San Francisco: Jossey-Bass.

Cohen, L., Manion, L., \& Morrison, K. (2007). Research Methods in education (6th ed.). London: Routledge Falmer.

Education, U. D. ((2011, October)). Trends in High School Dropout and Completion Rates in the United States:Compendium Report. USA: U.S. Department of Education. http://www.eric.ed.gov/PDFS/ED524955.pdf adresinden alındı

Evans, N., Forney, D., Guido, F., Renn, K., \& Lori, D. (2009). Patton student development in college:Theory, research, and practice. San Francisco: John Wiley \& Sons, Inc.

Fry, R. (2003). Hispanic youth dropping out of U.S. schools: Measuring the challenge. Pew Hispanic Center Website. http://pewhispanic.org/files/reports/19.pdf adresinden alındı

Fund, C. D. (2014). Children's Defense Fund (2004, June). The road to dropping out: Minority students and academic factors correlated with failure to complete high school. USA:Children's Defense Fund. http://www.childrensdefense.org/child-research-data-publications/ adresinden alındı

Hijazi, S., \& Naqvi, S. (2006). Factors afecting students' performance:The case of private colleges. Bangladesh e-Journal of Sociology.

Igwe, N. N., Ndidiamaka, M., \& Chidi, A. F. (2017). Principals leadership styles and students' academic performance in enugu metropolis:A comparative survey of public and mission secondary schools. Archives of Business Research, 5(8), 7-30.

Mekonnen, S. (2014). Problems challenging the academic performance of physics students in higher governmental institutions in the case of Arbaminch, Wolayita sodo, Hawassa and Dilla Universities. Natural Science, 6, 362-375. doi:10.4236/ns.2014.65037

Melese, W., \& Fenta, G. (2009). Trend and causes of female students dropout from teacher education institutions of Ethiopia:The case of Jimma University, Ethiopia. Journal of Education and Science, 5(1), 1-18.

Mersha, Y., Asrat., A., Bishaw, D., \& Nigussie, Y. (2009). The study of policy intervention on factors affecting female students' academic achievement and causes of attrition in higher learning institutions of Ethiopia. Ethiopia: Ministry of Education Gender Office.

Office, E. R. (2015). Raising student achievement through targeted actions. New Zealand: Crown.

Ortiz, A. M. (1999). The student affairs establishment and the institutionalization of the collegiate ideal. J. D. (Eds.) içinde, Reconceptualizing the collegiate ideal (s. 47-57). San Francisco: Jossey- Bass.

Robinson, V. M., Lloyd, C., \& Rowe, K. (2008). The impact of leadership on students outcomes:An analysis of the differential effects of leadership types. Educational Administration Quarterly, 44(5), 635-674. doi:10.1177/0013161X08321509

Silverman, D. (2005). Doing qualitative research. London: Sage Publications.

Tiruneh, W. A., \& Petros, P. (2014). Factors affecting female students' academic performance at higher education:The case of Bahir Dar University, Ethiopia. African Educational Research Journal, 2(4), 161-166. 
Waters, T., Marzano, R. J., \& McNulty, \&. B. (2003). Balanced leadership: what 30 years of research tells us about the effect of leadership on student achievement:A Working Paper. Aurora, CO: Mid-Continent Regional Educational Lab.

Yin, R. (2012). Applications ofcase study research (Third Ed.). London: Sage Publications Ltd.

Iletișim/Correspondence

Kelemu Zelalem Berhanu, Ikelemu@yahoo.com Prof.Dr. Ali Sabancı, alisabanci@akdeniz.edu.tr 